200 TRANSACTIONS OF THE GEOLOGICAL SOC. OF GLASGOW.

FORAMINIFERA.

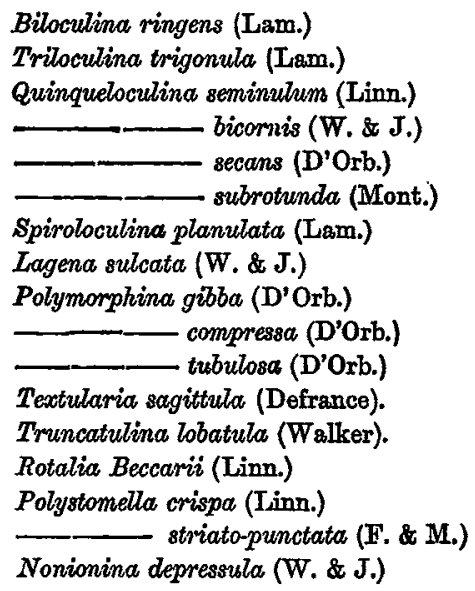

Cliona celata (Grant), burrows of

ALGA.
Rare.

Rare.

Common.

Moderately common.

Common.

Moderately common.

Rare.

Rare.

Common.

Moderately rare.

Moderately rare.

Moderately rare.

Moderately common.

Common.

Common.

Common.

Rare.

Common.

Cotnmon.

XIII.-On the GEOLOGY of the Istand of IsLAY.* By JAMtS THomson, F.G.S., corresponding member of the Royal Science Society of Liege, Belgium. With a Map.

[Read 13th May, 1875.]

THeRe are few parts of Scotland of which we know so little of the geological features as of those of the Island of Islay. The only information we have on the subject is to be found in $\mathrm{Dr}$ M'Culloch's " Highlands and Western Isles of Scotland," vol. ii., page 249 ; and by Prof. Nicol, in his "Geology of the North of Scotland."

Dr M'Culloch deals principally with the topographical aspect of the island, of which he gives a map and several sections. $\mathrm{He}$ describes the rocks in the central valley as being made up of

- The substance of this Paper was read at the meeting of the British Association in Edinburgh. 
Downloaded from http://trngl.lyellcollection.org/ at Indiana University Libraries on July 20, 2015

Trans. Geol. Soc.Glas.

Vol. V. Page 200

\section{IS I AY}

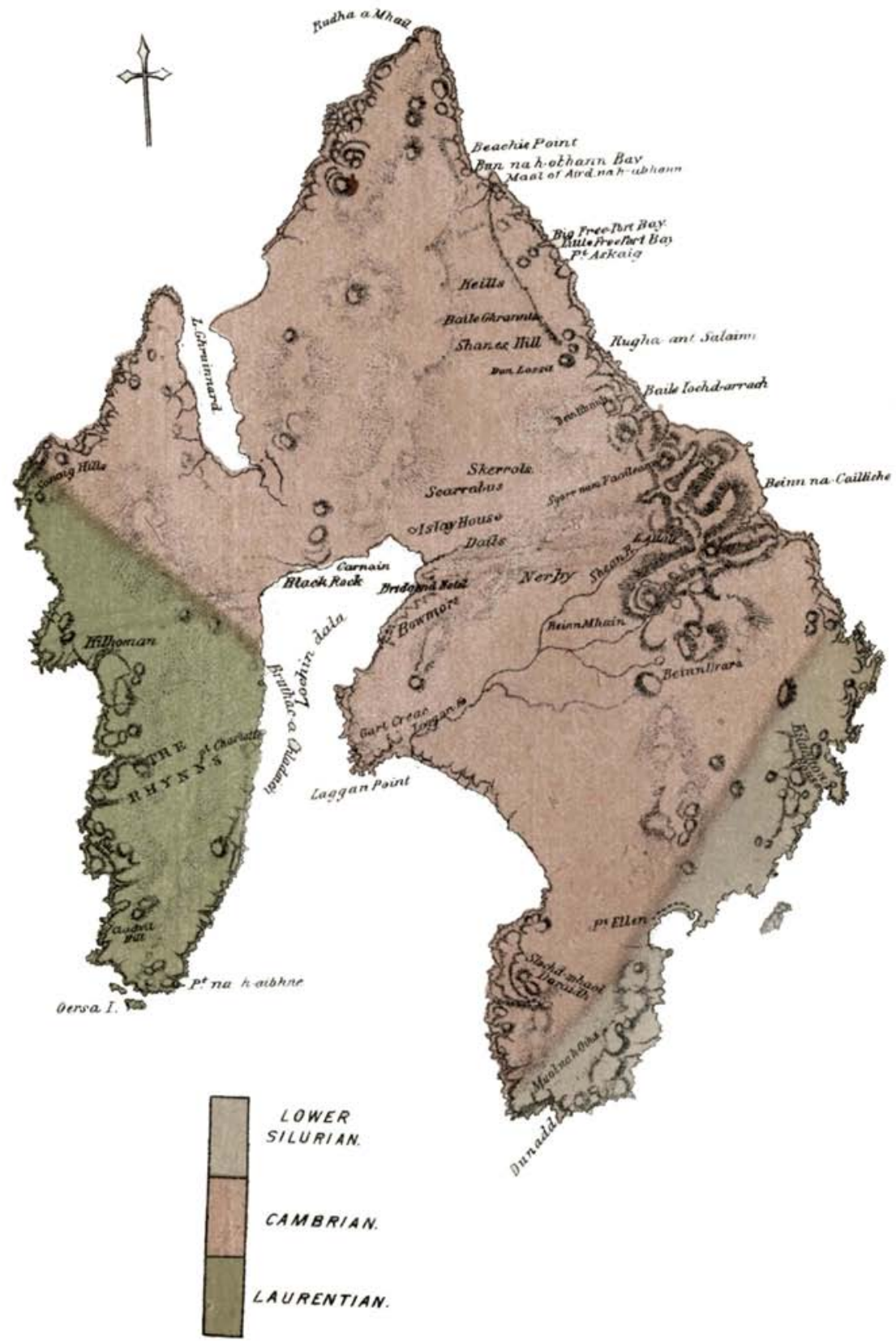


limestone, and notes the occurrence of granite boulders on the eastern side, and Prof. Nicol repeats these observations. But as neither of them identified the stratigraphical position of the rocks of Islay, the object of the present communication is to do so, and it will be best accomplished if I shortly notice, in detail, the stratified deposits. In order that their superposition and succession may be somewhat clearly defined, I have made a section of the most important points, which shows in succession the lithological order. I shall begin with the superior deposits on the south-eastern side, and review them downwards and westwards.

The southern end of the island is extended seawards in the form of a peninsula, which, from Slochd-mhaol-Doraidh in the north, to the Maol na h-Otha * in the south, is a distance of about seven miles, terminating at the Maol na h-Otha in bold water-worn precipitous eliffs, about 500 feet in height. The rocks here are quartzite, but on the south-west point, under Dunadd, + they consist of a gritty sandstone, with interstratified shales. The most notable of these is a band of chocolate-coloured argillaceous shale, imbedded in which are numerous masses of peroxide of manganese, varying in size from that of small peas up to pieces from 8 to 12 inches in diameter, the surface of these having a more or less mammalated aspect. These nodules, when broken, show radii of great beauty, and are delicately fibrous in structure. Their nucleus is usually of a different substance, sometimes appearing to be scoriaceous. In some instances the centre of the larger examples is broken up into irregular cellular chambers, which occasionally contain minute hexagonal crystals, of a delicate yellowish-green colour. If the manganese is dissolved in acid, it effervesces briskly. $\ddagger$

Masses of quartzite, made up of thin bands, are to be seen dipping under the sandstone, which overlies a thick bed of shale of a dark bluish-grey colour. This again overlies a series of beds of impure limestone, which splits up into thin flakes, some being

* Meaning Mull of Oa.

+ Dunadd is the remains of an old fort, supposed by some to have been built by the Danes, on their way to the battle of Largs, A.D. 1263.

¥ It is worthy of remark that, since the above was noted, Prof. Sir Wyville Thomson has discovered manganese in a red clay bottom, at a depth of upwards of 3000 fathoms, in various parts of the ocean. May not the red shale of the Islay section have been deposited under similar conditions? 


\section{2}

TRANSAOTIONS OF THE GEOLOGICAL SOO. OF GLASGOW.

not more than $\frac{1}{8}$ of an inch thick. Upon these flakes there are impressions of a very peculiar kind, some being attenuated to lines not thicker than the $\frac{1}{30}$ part of an inch, $\frac{3}{16}$ of an inch broad, and from 1 to 3 or 4 inches in length. They terminate at the opposite extremities in a somewhat clavate form; the structural characters cannot be made out in any of the examples that I have seen. *

On the east side of the Maol there is a deep gully, called Allt na meinne, $\uparrow$ produced by a small stream, which has cut a channel into a bed of impure graphite, in which are imbedded large cubes of sulphate of iron. This bed is overlaid by a bold escarpment of limestone, broken up into thin bands. The graphite overlies a mass of gritty sandstone, which passes into a breccia, and, by almost imperceptible gradations, into an arenaceous chlorite slate, interstratified with thin beds of quartzite, together about 400 feet high, and all dipping to the E. by E.N.E. Near the base of this section the beds have been contorted in a most remarkable manner, yet their stratification has not been obliterated. They are seen to dip on either side into a deep synclinal trough, of about 100 feet deep. In the centre, and near the base, the rocks are all more or less shattered into splintered fragments : a result produced by a local disturbing agent, which I, with limited time, was unable to discover. It must, however, be very local, as the rocks in close proximity all more or less dip to the s.E., corresponding with the general dip of the stratified rocks in the neighbourhood.

Proceeding to the north, along the crest of the promontory, we pass in succession over the upturned edges of beds of quartzite, shale, limestone, and chlorite schist, until we reach Slochd-mhaolDoraidh, on the west side of the point, where there is a mass of sandstone of a brownish colour, and in which we found patches of green carburet of copper, graduating into, and terminating on the shore in a coarse breccio-conglomerate. The sandstone is pierced and much altered by an extensive dyke of diorite, trending $E$. and by w. At the point of contact on the shore, the ceaseless roll of the Atlantic has abraded the under portion of the cliff, and has formed caves of considerable dimensions, where the chough and other rare birds resort during the breeding season.

* In outline these forms resemble some of the species of Graptolites.

+ In Finglish Ore brook. 
THOMSON-ON THE GEOLOGY OF ISLAND OF ISLAY.

On the east side of the peninsula, in Port Ellen bay, the sandstone is again seen graduating into breccio-conglomerate, which consists of pebbles of quartz, varying from the size of a pea to three inches in diameter. It is there seen to be cut off by a syenitic diorite dyke, exposing, on the west side, the breccia, and on the east, a talcose schist of a dull red colour, with occasional patches of that silvery, metallic lustre so characteristic of this rock.

The schistose rocks trend eastward for about ten miles, and are seen all along the hill-sides, exposing in many places sections of contortions similar to those often met with in the lower Silurian rocks of the Highlands of Scotland. They contain, here and there, lenticular masses of white quartz, and steadily dip to the s.E. They are pierced by numerous igneous rocks, belonging to different periods of time, some being of a dull green colour, interspersed with large crystals of olivine and long crystals of hornblende. They seem to have been ejected through the strata at an early period, probably about the time the upper members of the Silurians were deposited, whilst the compact basalts and diorites have been thrown up at a much later date.* Their trend is from N.W. to S.E., and in many places they pierce the stratified rocks at right angles, and not unfrequently some of them cut through the older igneous rocks. Prominent amongst the later ones are those in the neighbourhood of Knockhill, to the north of Kildalton House. They have been ejected through the schistose rocks, and have shattered them into splintered fragments. Knockhill is composed of a syenite, with large crystals of hornblende; it is difficult to break, and takes a beautiful polish.

Bordering this coast of Islay is seen a succession of terraces, with, here and there, abrupt, rugged ridges, composed of the harder rocks which have resisted the abrading influence of the sea, giving this part of the island a wild and rugged aspect. But where the natural wooding has sprung up, as in the locality just mentioned, it gives the otherwise bleak moorland flat, with its rugged knolls, a picturesque beauty. All along the south-east portion of the island there is evidence of the erosive action of the sea at different elevations. Indeed, ridges and terraces may be traced, rising tier after tier, up to near the southern extremity of Beinn Urara. The schist rocks extend inland for three and a half 


\section{TRANSACTIONS OF THE GEOLOGICAT SOC. OF GLASGOW.}

miles, when they are seen to overlie a quartzite of a dull brown colour, intermixed with a pink variety. This quartzite may be traced passing through the mountain range to the north-east, and terminating in the Sound of Islay. Three miles to the north of Kildalton House, the junction is marked by a breccia, consisting of fragments of quartzite nearly pure white, with pink lines passing through it, intermixed and cemented together by a brown silicious matrix. It is seen trending $s$. and by w., and passing to the Sound of Islay, terminating near Sgorr nam Faoileann.*

A little way further inland we pass over an extensive ridge of quartzite, trending $\mathbf{E}$ and by $\mathbf{w}$., from Sgorr nam Faoileann in the east, where it assumes a series of bold, and more or less conical, mountains, the most conspicuous of which is Beinn Bhiogair, +1600 feet above sea-level, with Beinn Mhain $¥$ to the west, and Beinn Urara $\S$ to the south, 1400 feet high. It descends, in undulating slopes, to the south-west, terminating near Port Ellen, where the overlying quartzite graduates into the coarse breccio-conglomerate formerly referred to.

In passing northwards, on the west side of the island, we find the rocks more or less concealed by gravel and drifted sand for about eight miles, || until we cross the Laggan Water, where they again appear, in the form of a ridge of dull grey quartzite, trending s.w. by N.E., broken up into thin bands, and graduating into a dull bluish-grey impure limestone, succeeded by a grey slaty shale, with numerous imbedded crystals of iron pyrites, which crumble into fragments on exposure to the air, and all overlying a mass of quartzose chlorite schist, on the shores of Lochin dala. These all dip steadily to the s.x., till near the village of Bowmore, where it is difficult to determine the dip and strike, in consequence of an extensive boss of dolerite, which bas dislocated and shattered the stratified rocks into splintered fragments. To the east and west, however, of the igneous rocks, the

* Meaning Scaur of the Seagull.

+ Meaning Hill of the vicar.

F Meaning Hill of the waste land.

$\$$ Meaning Easily ascended hill; shelving out further in the range.

II As the trend of these rocks is from north-east to south-west, they are exposed on the north-east in water-worn cliffs along the shore of the sound of Islay. I shall therefore notice them in detail, when I come to describe the stratified rocks on the east side of the island. 


\section{THOMSON-ON THE GEOLOGY OF ISLAND OF ISLAY. 205}

quartzites are seen steadily dipping to the S.E. To the west of Bow- Lower more there is a band of arenaceous talcose schist, in which are found embedded fragments and boulders of quartzite, similar to those found on the east side and in the centre of the island, and which we shall note, in detail, by-and-by. These pass, by imperceptible gradations, into a chocolate-coloured shale, with interstratified chlorite schist of a corresponding colour, for a distance of about two miles, till at Gart breac,* where the stratified rocks are again much altered by intrusive igneous rocks, which here emerge from the sea. In trending westwards, the quartzites are more or less intermixed with those of a dull bluishgrey colour, varied with a pinkish variety, which at some places approximates to a felsite, until we reach Laggan point, where they are lost to view in the sea. It is noteworthy that these rocks are all more or less uniform, both in colour and composition, with those on the opposite side of the loch, suggesting a continuity of the same stratified rocks below the sea. This idea is rendered very probable by the fact that on each shore they are all more or less affected by similar igneous rocks. Indeed, on each side, the quartzites and schists are occasionally shattered into splintered fragments, and dip to all angles of the compass, varying from $15^{\circ}$ to $70^{\circ}$.

\section{* Meaning Spotted farm.}

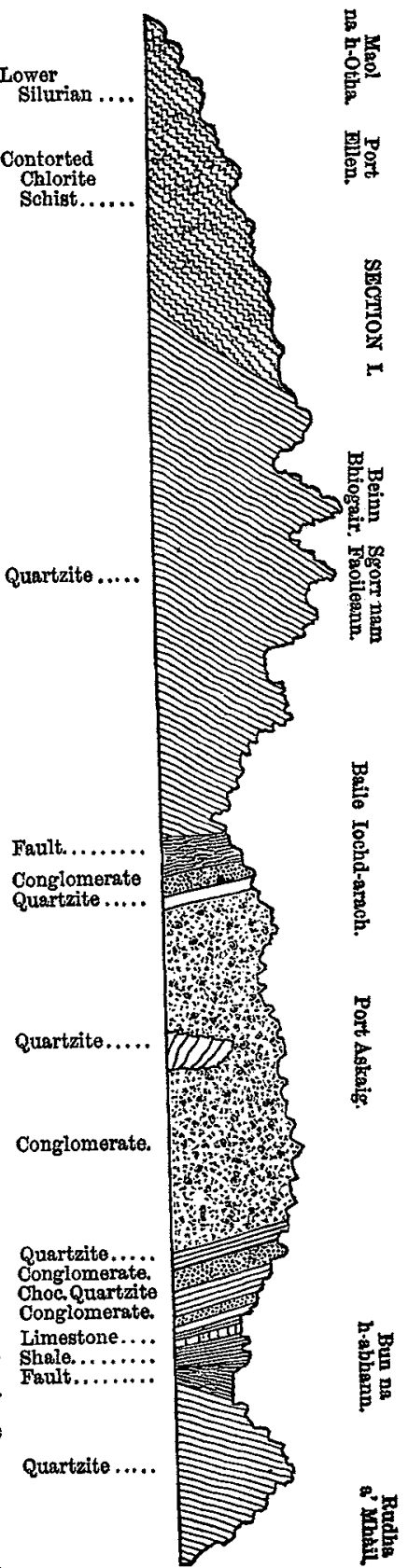




\section{TRANSAOTIONS OF THE GEOLOGICAL SOO. OF GLASGOW.}

Let us now take a cursory glance at the stratified rocks found in the centre of the valley, beginning in the north, and passing to Beinn Mhain, on the north-west extremity of that range of quartzite hills formerly referred to; and from the shore of Lochin dala, on the west, from which the land rises with a gradual ascent, reaching an altitude of about 600 feet, and terminating in the Sound of Islay, in precipitous water-worn cliffs.

On the north side of the island there is a series of undulating hills, consisting of quartzites, and forming a continuous range all along the N.W. seaboard, from the N.E. point at Rudha a' Mhail to Loch Ghruinnard, in the west, while the landward portion of the series terminates at Black Rock and Carnain. Indeed, the ranges of quartzite and stratified rocks trend from the shore in the east to the opposite shore on the west.

In the farm of Scarrabus the quartzite range is flanked and overlaid by a broad belt of sandstone, containing minute crystals of iron pyrites, which in turn is overlaid by an impure limestone, made up of numerous thin bands, and these pass with imperceptible gradations into the overlying calcareous shale which, on exposure to the weather, splits up into thin flakes, and all dipping E.E. S.E. ang. $44^{\circ}$. These calcareous shales become more arenaceous, and finally pass into a fine-grained quartzose sandstone, which is overlaid by a broad belt of bluish grey quartzite, which trends to the s.w. and terminates on the shore of Lochin dàla at Carnain. This again is overlaid by a belt of soft chlorite schist, of a dull grey ochrey colour, which, when exposed to the weather, splits up into thin scaly fragments, the dip being E.E. S.E. ang. $61^{\circ}$. Above it lies a bed of limestone, which in turn is succeeded by a series of thin beds of arenaceous chlorite schist of a dull ochrey colour, capped with a dark blue quartzite, which forms a conspicuous ridge, and is seen trending to the west, and terminates at the north corner of Lochin dàla, near Islay House.

In the farm of Octorulin this quartzite passes into a dull grey sandstone, which is overlaid by an extensive bed of a greyish purple arenaceous talcose schist, containing numerous minute crystals of iron pyrites. Interspersed throughout this schist are rounded and angular fragments and boulders of granite, gneiss, and white quartzite, which may be termed a breccio-conglomerate, which when exposed to the weather, becomes of a reddish brown colour, with ferruginous stains along the joints and planes of 
THOMSON-ON THE GEOLOGY OF ISLAND OF ISLAY.

stratification; its dip is E.S.E., ang. $28^{\circ}$. This is overlaid in the farm of Skerrols by a broad belt of limestone, made up of thin bands, intersected with numerous ramifying veins of calc spar, and interstratified with partings of arenaceous shale; its dip is S.E. ang. $34^{\circ}$, and its trend N.E. to S.W. from near the Sound of Islay in the north, and terminating south of Bridgend Hotel,* on the shore of Lochin dàla. This limestone is overlaid by chlorite schist, and is only seen at intervals, as it is concealed by moss and surface vegetation. It is, however, well exposed in the banks of the river Sorn, in the wood below Dail's farm house. To the south, which is covered by an extensive band of limestone with occasional partings of arenaceous shale, and seen trending to the s.w. and exposed in a cutting on the road from Bridgend to Port Ellen. In ascending the rising ground to the south, the limestone is more or less exposed till it reaches the farm of Nerby, where it is interstratified with bands of chlorite schist, of a chocolate colour, its dip being E.S.E. and angle $75^{\circ}$. It is capped by a ridge of quartzite trending E.N.E. to W.S.W., of which the dip is S.S.E. and the angle $68^{\circ}$. To the s.E. the quartzite is succeeded by a bed of clay slate, containing large crystals of iron pyrites. This quartzite, limestone, and chlorite schist, form a prominent ridge, and cross the Port Ellen Road to the w.s.w. (as formerly referred to), and terminate in the shore at Laggan farm. In descending the valley to the S.E. of Nerby farm, a band of impure limestone is seen overlying the clay slate, with an abrupt termination, caused by the erosive action of the sea when the valley and strath were all under water. The well-marked terraces of sand and gravel on either side give ample testimony that they were deposited in a post-pliocene age, while bere and there the harder rocks are left as prominent knolls, the interstices being filled with peat-moss and brown heath. On the crest of one of the most prominent of these ridges are to be seen the remains of a Danish fort of considerable dimensions. It is of an elipsoid form, showing a series of earthen outwalls, with an inner quadrangle 84 feet long.

In passing to the S.E. the stratified rocks are concealed by boulder drift. The clay is of a light bluish-grey, containing angular, subangular, and rounded boulders of limestone, quartzite

* This is perhaps one of the most charming spots in the West Highlands; and there is a very comfortable hotel. 
of various colours, dull green dolerite, with large crystals of pale green olivine and hypersthenic syenite. About half a mile to the s.E. a limestone is again seen interstratified with clay slate, chlorite schist, and quartzite, until we come to the Shean river, along the banks of which are exposed rocks of a similar character until near the top of the glen, where there is an extensive mass of saccharine limestone, which in some places is nearly white, passing into a pinkish grey variety. This is broken up in the upper part of the exposed section, with thin bands interstratified with arenaceous shale, in which, though searched with care, I have not yet found organic remains, but I do not yet despair of doing so. Along the line of junction, the quartzite is seen to overlie the saccharine marble and calcareous shales. Several of the mountain streams have eroded deep underground channels into the calcareous rocks, and are lost to view for a considerable distance, again re-appearing in the banks of the river Shean. One of the caverns made in this way is of considerable size. This limestone is seen crossing the valley and ascending the steep slopes of Beinn Mhain, and may be traced for miles trending to the s.s.w. On the eastern extremity it is much altered and shattered by a broad dyke of dolerite of a dull green colour, containing pale green crystals. At the point of contact the igneous rock is not only lighter in colour, but is also finer in crystallization, and trends from $\mathrm{N}$. to $\mathrm{s}$. It can be traced for a considerable distance to the north, and to the south it is seen descending and crossing the upper reaches of the river Shean, being there lost to view in the talus and remains of ice-drift, until at an altitude of 1340 feet, where it is 16 feet broad, and where it has been ejected through a brecciated quartzite, which at the point of contact is shattered into splintered fragments, with the igneous rock filling up the interstices, and mixing with the breccia. The junction is seen for about 100 feet higher, where it is again lost, re-appearing at the height of 1560 feet, and to the summit of Beinn Bhiogair, is then exposed 1600 feet, where there is evidence that here was a centre or vent of volcanic force, as the rocks around are all shattered into splintered fragments.

At the upper extremity, and a short distance to the north-east of the glen, there is a deep basin, in the middle of which lies a small loch called Loch Allaly, with a little island in the centre. This loch is bounded on the west by the igneous rocks just referred to, 
and on the east and south-east by gritty quartzites, which rise in terrace after terrace like cyclopean walls. On the east lies Sgorr nam Faoileann, ${ }^{*}$ which is fully 1400 feet high. Then passing to the south we find a ridge of brecciated quartzite at least 1000 feet high, and formerly the water-shed between Glen Choridalet on the east, where the descent is steep and rugged, and Glen Shean on the west, while to the south it joins the steep and rugged side of Beinn Bhiogair, which, as previously stated, is shattered into splintered fragments by the action of the igneous rocks. On the south-west face the quartzite and breccia are of a dull red or pinkish tint. They continue down into Glen Shean, and emerge on the north face of Beinn Mhain, the dip of the quartzite-where not affected by igneous action-being steadily to s.E. Indeed, if the observer passes from the lofty summit of Beinn Bhiogair, and across the ridge to Sgorr nam Faoileann to the north, the quartzites can be traced passing through the body of the hill to the S.E., and terminating on the opposite or the rugged and precipitous face of Glen Choridale, while to the north on Beinn Mhain, and to the south all along the range to Beinn Urara, and Beinn na Cailliche + on the south-east, the quartzites are seen still dipping to the S.E.

The long axes of the ranges form conspicuous ridges throughout the island, the general trend being from N.E. to S.W., while the depressions are all more or less filled up with schist, slates, and limestones. In Glen Shean, on the west, these stratified rocks are here and there seen, and dipping to the S.E. On the farm of Kinnagary, on the side of Beinn Mhain, the junction of the overlying quartzite, and the calcareous deposits can be traced by the marked change in the vegetation. All along the strath the limestone rocks may be traced by the soft green surface-growth, while above the quartzites the shaggy heath and stunted scanty grasses show how poorly the soil, resulting from their decomposition, supplies the elements favourable to plant life.

The stratified rocks which we have thus briefly reviewed, and which are seen to overlie the great body of quartzites on the north-west side of the island, and occupying a space of about six miles, all steadily dip to the s.E., at angles varying from $28^{\circ}$ to $75^{\circ}$. If, however, we take the average of the angles of dip, we have $33^{\circ}$, almost equal to one-third of $100^{\circ}$, and in the same way divide

* Meaning Glen of the caldron pool. + Meaning Hill of the old woman. 


\section{0}

TRANSACTIONS OF THE GEOLOGICAL SOC. OF GLASGOW.

the six miles of extent by 3 , we have two miles, so that if these six miles of deposits, dipping at an angle of $33^{\circ}$, be placed at right angles to the plane of stratification, they will represent two miles, or 10,560 feet of sedimentary rocks, which fill up the central valley, reposing on the quartzites in the north-west, and overlaid by the great body of quartzites in the centre of the island.

I now propose to notice shortly the stratified deposits from Baile Iochd-arach * in the south, to Bun na h-abhann in the north, where they are all exposed in an ascending series on the sea-cliffs, dipping N.N.W. At Port Askaig a ridge of dull blue quartzite is seen in a bold precipitous face, 70 feet in height. It is made up of more than a hundred thin bands, varying from two inches to two feet in thickness, and trending w. by E., the dip being N.W., and the angle $12^{\circ}$. Underlying this, the shore is fringed for $3 \frac{1}{2}$ miles by a series of sedimentary rocks, consisting of a dull bluish-grey arenaceous talcose schist, exhibiting faint lines of stratification, whilst in other parts of the section it resembles the unstratified deposits of more recent times.

On the north side of Little Free-Port Bay, blocks were recently being quarried to build a new pier at Port Askaig, which exposed a section about 100 feet deep, and showing numerous imbedded fragments and boulders of transported rocks. At its base there is a dull bluish-grey arenaceous schist, shading, as it passes upwards, into a light brownish grey. In the earlier stages of the deposits the matrix had been soft and plastic, into which the transported fragments and boulders had been dropped, with subsequently a great influx of arenaceous matter. It thus passed with almost imperceptible gradations from a stiff blue talcose mass in the inferior, to a gritty sandstone in the superior deposits. There is, therefore, evidence of great physical changes throughout. The contained pebbles and boulders are frequently well waterworn, others subangular, whilst others again are angular. They chiefly consist of granite, quartzite, and rarely gneiss. Some of the granites much resemble a variety met with in the range of mountains to the south of Ben Nevis. It is of a dull red colour, the greater portion of its mineral constituents consisting of a reddish felspar. In this section the heaviest blocks and finest particles are commingled, and form a confused mass, in which I have detected not less than thirty-seven varieties of granite, and a

* Meaning Nether farm, or Netherton. 
THOMSON-ON THE GEOLOGY OF ISLAND OF ISLAY.

few examples of gneiss. Over and around the boulders the schist is deposited evenly, while inferior layers are squeezed downwards, crushing and destroying the planes of stratification. It is noteworthy that I have not found a single specimen of trap rock in this section. The granite fragments largely predominate, and vary in size from the smallest pieces possible to boulders as large as 4 feet 10 inches in diameter. I estimate the proportion of quartzite approximately to that of granite as 1 to 15. After a careful examination of the shore, and of the blocks embedded in the matrix, I am satisfied that these erratics could not be traced as belonging to any part of the island. Similar rocks do not occur in situ nearer than forty miles to the north, in the island of Mull, with a deep sea intervening, while some of the varieties only exist at a considerably greater distance. The entire absence of stratification in one part of the section, which in another shows signs of regular deposition, and the occurrence of far transported rocks of the character already stated, indicate that the mass had been transported and dropped from melting ice in a shallow, tranquil sea, the bottom consisting of mud and sand. The absence of stratification in one part of the section may be accounted for by the disturbing action of icebergs which moved to and fro, grounding as they went before they were finally stranded. I was, however, anxious to find further proofs of ice action, such as well-marked striations on rock surfaces would afford, but such evidence was of course obscured by subsequent depositions, and only on those parts of the ancient rock-surfaces which had escaped destruction by denudation could such striations be found On the north side of Little Free-Port Bay the quarrying operations already spoken of had laid bare a piece of transported quartzite rock, the surface of which was ground, smoothed, and striated, and as perfectly preserved as in rocks of more recent times.

The deepest section of the conglomerate exposed from the shore line to the crest of the water-worn cliffs is 130 feet, and is capped by quartzite bands graduating into a gritty sandstone, which passes into a brecciated conglomerate, ${ }^{*}$ evidently an old shore line of sand, and containing transported fragments and boulders of granite, and traceable inland to an altitude of 180 feet, where

\footnotetext{
* It has been suggested that marine plants might have been the agent of transport, but in regard to blocks of a size here found, such a theory is not admissible.
} 


\section{TRANSACTIONS OF THE GEOLOGICAL SOC. OF GLASGOW.}

its upturned edges are exposed, curving round the hillside in a semi-circular form, and dipping to the N.W., the ang. being $48^{\circ}$, and again bending down to the shore line at Port Askaig Hotel, where I first discovered the remarkable erratics above described. It then trends to the s. at Baile Iochd-arach, a distance of about two miles, and is there cut off by a diorite dyke. In rounding the point into Big Free-Port Bay, the gritty sandstone is seen to be overlaid by an extensive bed of quartzite, broken up into thin bands, which are found ascending the hillside and folding round the underlying deposits, and also passing to the south, and bending down to the shore at Rugha an t-Salainn, where the planes of stratification are much affected by a syenitic greenstone dyke trending W.N.W. by E.S.E. Indeed, the stratified rocks seem to have been deposited over and around the dark bluish-grey quartzite at Port Askaig, which seems to be the only fragment left of the old shore line, and is probably of pre-Cambrian age. They all dip N.W., while to the south, atong the shore, the quartzites and stratified rocks dip steadily to the s.s.E. The frequent occurrence of igneous rocks in the neighbourhood of Rugha an t-Salainn, and the marked alteration in the dip of the stratified rocks there-the stratified deposits dipping to the N.W. on the north side of the line of fault to near Keills, while on the south side they dip to the S.S.E. This indicates that here we may trace and account for the throwing up of the underlying drifted matter to the surface, while on the north-west side of the island, at Skerrol's farm, similar drifted materials are found to underlie all the calcareous and stratified rocks of the centre of Islay. This, however, will be better understood when we pass in detail the stratified rocks to the north of Port Askaig.

In passing to the north of Big Free-Port Bay, the quartzite is overlaid by a band of talcose schist, which in turn is overlaid by a succession of thin-bedded greenish-grey micaceous sandstone flags, interstratified with dull chocolate-coloured argillaceous partings. The surfaces of these flags are not unfrequently covered with sun-cracks, with upturned edges of various forms and sizes, the result of shrinkage from sun heat, and which are subsequently filled up with, and silted over by, the influx of sedimentary matter. They also contain ripple marks, in the depressions of which are numerous little pits, with upstanding edges, varying in size from half a line to two lines in diameter. These possibly are 
THOMSON-ON THE GEOLOGY OF ISLAND OF ISLAY.

the impressions of rain-drops found in the soft partings during deposition. This section is fully 100 feet deep, and is overlaid by a series of pinkish-coloured quartzite bands, which again are covered by sandstone, calcareous shales, and impure limestones on the farm of Aird na hughadh.

This depth of calcareous accumulations is followed by almost purely arenaceous deposits, which mingling with the later sediments of the preceding formations, produce near the junction of the two, a calcareous sandstone. It is overlaid by quartzite, which is cut off by a diorite dyke. On the north side of the dyke there is a mass of arenaceous schist about 200 Jards broad, containing fragments and boulders of granite. At first sight I thought these deposits might be a continuation of those beds further to the south, which had been brought up by the diorite dyke just referred to, bat after a careful examination of the surrounding strata, when I found the matrix of the latter to be of a more gritty character, I am inclined to place them higher, which would indicate a repetition of similar conditions at great intervals of time. Indeed, the phenomena occurring at several points along the coast line, however local they may be in their extent, point to physical changes similar to those of more recent times.

These deposits are succeeded and overlaid by a broad band of quartzite, which dips $25^{\circ}$ to the N.W., and are followed by calcareous shale and impure limestone, with interstratified bands of quartzite. This is overlaid by beds of gritty sandstone, of a dull brown colour, interstratified with calcareous partings, to which succeeds a dull grey quartzite, which in turn is capped by a broad belt of dark slaty shale, interstratified with thin quartzite bands, which vary from one inch to several feet in thickness, and interlaminated with dark grey shale, containing imbedded crystals of iron pyrites. These, when exposed to the weather, become yellowish-brown, rotten rock, splitting into thin layers; their dip is to the N.W., $72^{\circ}$. This high angle is produced by a diorite dyke. These sedimentary rocks pass inland, bending with a gentle curve to the south, and are found on the crown of Knock Aird na hughadh, formerly referred to. They trend to the s.w., and are seen at Shanes Hill, and westward to Skerrols. At the Maol of Aird na h-abhann they are again seen to be overlaid by quartzite of a dull brown colour, its dip being to the N.w., at an angle of $68^{\circ}$, which at 200 yards from the point of the Maol, 


\section{TRANSACTIONS OF THE GEOLOGICAL SOC. OF GLASGOW.}

graduates down to an angle of $25^{\circ}$ N.W., and there plunges below sea level in the Bay of Bun ua h-abhann.* It re-appears on the opposite shore at Beachie Point, where it rises with a reverse inclination, the dip being S.S.E., ang. $47^{\circ}$, and passes to the north in a series of bold conical mountains. The centre of this bay is a synclinal trough, where the quartzite is a white vitreous mass, crushed and shattered into splintered fragments, it being almost impossible to detect the planes of stratification. At first sight I thought the quartzite on the north shore of the bay was unconformable to that on the south, but after a careful examination, I am disposed to think that it was one continuous super-imposed mass, and that the centre of the bay is the line of a great downcast fault, trending S.W. by N.E.

As before noticed, to the south of the conglomerate section the quartzites (as in the north) rise into a series of bold conical mountains, and is seen forming the steep slopes of Beinn Dhubh $\uparrow$ in thin bands, which are seen folding and clasping round the dull red breccia which forms the nucleus of this part of the range. The valley of Rugha an t-Salainn is a line of fault; on the north side the dip of the quartzite is N.W., while on the opposite side of the valley it is to the s.E. The quartzite here overlies the eastern extremity of the saccharine limestone, which terminates a few feet from the Sound of Islay, and trends to the s.w., in Glen Allaly. A few hundred yards inland the saccharine limestone overlies other calcareous deposits, and the soft interstratified shales have been eroded away, leaving the hard upturned edges of the quartzite and limestone as prominent ridges facing northwards, and which, although covered by vegetation, can be traced along the hillside, rising terrace after terrace, like the more recent raised beaches.

In observing the outcrop of these rocks along the shore line from Baile Iochd-arach on the south, to the Maol of Bun na h-abhann on the north, it will be seen that though they present considerable changes in the lithological characters, their general succession is very similar to those of the transverse section on the north side of the centre of the island. The dip and strike of these beds differs so widely from those of the south and central portion of the island, that the idea is suggested of some

* Meaning Outlet of the water. + Meaning Black Hill. 
THOMSON-ON THE GEOLOGY OF ISLAND OF ISLAY.

great physical agency, which had been the means of producing such divergent results. All along the eastern shore line, and for a short distance inland, the general dip of Laurentian... the beds is to the N.W., while in the south and in the northern part of the island the dip is to the s.E. The only probable cause that I can assign for these deposits dipping at right angles to each other, is the frequency of the diorite dykes. In the neighbourhood of Baile Iochd-arach, where the line of fault is so well seen, the trend of the dykes is from S.S.E. to N.N.W., and they all more or less converge inland to the centre of the valley, lying to the north of Baile Ghrannta, where there is evidence of some great local disturbance by volcanic agencies, and which seems to have been the centre or volcanic B vent from whence the igneous masses have been erupted through the Conglomerate. stratified rocks, and which had upraiced the underlying wartzite..... upraised the underlying conglomer- shale ........ ates and super-imposed stratified deposits. This is confirmed by the Clay shale... fact that along the line of fault is a line of depression which extends Slatey Shale. inland to the north of Baile Ghrannta, and then trending to the N.E., Iimestone....

Dyke......

Limestoni..... terminates at Bun na h-abhann Bay, thus inglosing in a somemb tri angular form the upraised lower deposits, which are now exposed along the shore line. Subsequently the overlying stratified rocks have been denuded away by ice-action and by that of the sea.

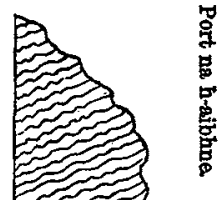
Limestono. Quartzite ..... Limestone..... Limestone.... Conglomerate. Quarteite.... Conglomerate.

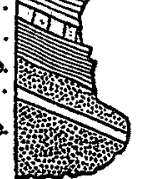
富 


\section{TRANSACTTONS OF THE GEOLOGICAL SOC. OF GLASGOW.}

In order that the relation of these deposits may be clearly understood, let us take a cursory glance at the stratified rocks from the east to the west side of the island. In following the track of the high road from Port Askaig on the east to Port na h-aibhne on the west, we pass over the upturned edges of the stratified rocks, most of which have been already mentioned in crossing the centre of the island, in a somewhat diagonal manner. Going westwards from Port Askaig for about a quarter of a mile, we pass over the upturned edges of chlorite schist, quartzite, brecciated conglomorate, micaceous flags with felspathic partings, and a body of quartzite which forms the crown of the ridge. In descending from this to a small valley, we find the stratified rocks concealed by the super-incumbent vegetation. We believe them, however, to be a continuation of the calcareous shales seen on the shore line beyond Big Free-Port Bay. Overlying this there is a broad belt of limestone of a dull blue colour. This limestone, when exposed to the weather, shows a granular or oolitic appearance, which $I$ thought might be due to minute organic forms. I had some of the most promising specimens sliced for the microscope, and on examination, found the granular form to consist of small spherical aggregations of iron pyrites through the matrix. This limestone is broken up into thin bands, with interstratified thin beds of gritty shale, and then passes into light buffcoloured saccharine limestone, which in turn is overlaid by quartzite of a similar colour. These all dip to the N.W., and pass into a pinkish colour at Keills. Further to the west we pass over thin bands of quartzite, interstratified with dark shale. These quartzites vary from an inch to several feet in thickness, and trend N.E. to S.W., the dip being s.E. At about a mile to the east they are again seen in the crest of Knock Aird na hughadh, at an elevation of 480 feet, their upturned edges being there exposed, with a dip to N.N.W., the angle being $72^{\circ}$. These rocks within a limited area dip at a right angle, which has been produced by a diorite dyke, formerly referred to as passing along the line of fault north-west from Baile Iochd-arach. A short distance to the east, we pass over the most extensive body of limestone in the island, and which has long been mined for galena. It is interstratified with dark shale partings, and is overlaid by a dark slatey shale, which is more or less seen till we reach Baile Ghrannta, where there is a broad dyke of diorite exupted through a bluish lime- 
THOMSON-ON THE GEOLOGY OF ISLAND OF ISLAY.

stone, which is made up of thin bands with partings of micaceous shale. The dislocation produced by the intrusive dyke is of limited extent. On its west side the limestone is thrown up at right angles to the plane of stratification, whilst on the east side the beds dip at an opposite anglo-dip E.S.E. To the west for about half a mile, the upturned edges of the hard stratified rocks are occasionally seen in rugged knolls, while the intermediate spaces are filled up with boulder drift, and super-imposed vegetation, till we reach Shanes Hill, the western slopes of which consist of quartzite. On the east side there is a succession of dark slaty shales, interstratified with impure limestone. These stratified rocks are much affected by an intrusive diorite dyke; the alteration caused by which, however, is local, the general dip being s.E. For a distance of nearly three miles, the stratified rocks are much concealed by ice drift. The majority of the boulders are traceable as having come from the west, and are all more or less scratched and polished, the usual accompaniments of ice action.

To the west, and in the neighbourhood of Islay House, there is an extensive belt of quartzite of a dull bluish colour, which, as before stated, trends to the west, and is seen on the shore of Lochin dala, near Bridgend Hotel. Along the shore to the west the arenaceous talcose schist, with imbedded fragments and boulders of, granite, are seen in the wood, are lost under the sea, and re-appear to the west of Bowmore village, on the opposite side of the Loch. They are overlaid by a dull bluish quartzite, which at Carnain is seen to pass inland and form a ridge, some of its hills being of considerable height. To the west the underlying stratified rocks are concealed by gravel and drift sand for a distance of two miles. The pebbles exhibit all the varieties of quartzite, from a bluish-grey to an almost pure white. Going inland towards the north, and along the low flat-lying strath of Ghruinnard, where lie the upper reaches of Loch Ghruinnard, the subsoil of the strath is made up of recent shells for a depth of from four to five feet. On the north-west side of the strath the rocks exposed consist of quartzites and chlorite schists, all more or less of a chocolate colour, till at Sanaig hills, on the shore, they end in bold water cliffs, the highest of which is somewhere about 600 feet. The stratified rocks are here seen to pass into a bluish-grey chlorite slate. These slates are often crushed and broken into every conceivable angle by intrusive igneous 


\section{TRANSACTIONS OF THE GEOLOGICAL SOC. OF GLASGOW.}

rocks, consisting of compact basaltic diorites. One of these dykes is 12 feet broad, and the columns are lying horizontally. All along the shore line, and at the junction of the igneous rocks, the stratified rocks are eroded away into deep gullies, one of which is called Gairtean Ghille Mhoire; it is about 400 feet long, and at the deepest part about 600 feet in depth, that is from the crest of the hill to the shore line, and twenty feet broad. At the upper portion of the gorge the rocks consist of a dark blue brecciated shale, while seawards they are arenaceous chlorite schist, interstratified with blue gritty quartzite. These all dip to the S.S.E., and present on the shore line a series of rugged cliffs. In passing inland and to the s.w. the rocks dip to s.E., till we reach Balinaby,* where, however, the angle of inclination is seen to alter near the parish church of Kilhoman, being the dip to the N.W., and the quartzites, schists, and slates are seen to overlie and fold round the gneissic rocks, of which the western extremity of the island is made up. On the east side of theridge Bruthac a' chladaich, + the talcose schist and quartzites are more or less of a light chocolate colour, and are seen dipping to the S.E. They are here cut off by a felspathic dyke of a dull red colour, trending N. and s., which a few yards inland is covered with sand and gravel. A little to the south-west there is a compact diorite dyke, erupted through the stratified slates and gneissic schists, and it has crushed and destroyed the planes of stratification, the dip being to every point of the compass. At this point a complete change both in mineral character and physical conditions takes place. There is a band of felsite of a pinkish colour, with lenticular masses of white quartz imbedded, and crushed into splintered fragments, the result of the neighbouring intrusive igneous rocks. The gneiss is here overlaid by a band of clay slate, which may be traced passing through the promontory to Cille Chiaran on the west shore, where it has been quarried for roofing purposes. It is seen clasping and folding round the gneiss, and in turn is overlaid by an extensive mass of quartzite to the north, which dips N. $82^{\circ}$.

Inland, about 200 yards from the slate quarry, the gneiss is pierced by a hypersthenic syenite dyke, trending w. by $\mathbf{E}$, being tilted up nearly at right angles to the plane of stratification a short distance to the south. For about two

* Meaning Abbot's farm. + Meaning Hill on the Shore. 
miles, the gneiss dips S.S.w., till on the south-west of Cladvil hill it is seen dipping w.S.w. In descending to the plain we pass over a broad belt of highly metamorphosed gneissic chlorite schist, which graduates into a granitic gneiss, varying in colour from a dull green to a pinkish variety.

From Bruthac a' chladaich along the shore line to Port Charlotte and to the western end of the peninsula, where a few hundred yards out there lie two small islands, upon one of which, the island of Oersa, Port na h-aibhne lighthouse is built, the rocks here and for nine miles inland, are essentially different from those found throughout the island. They consist of highly metamorphosed stratified rocks, such as greenish-grey gneiss, pinkrish-grey gneiss, with crystals of hornblende, quartzite, chlorite schist, bluish grey dolomite, which slightly effervesces when acted upon by dilute acid, serpentine, of a deep green colour interspersed with yellow crystals of various shades, and hypersthene interstratified, and dipping S.S.W. at an angle of $68^{\circ}$. These are pierced at frequent intervals by diorite dykes of considerable dimensions, for nine miles, and these pass inland at right angles to the plane of stratification. Although geographically associated with these rocks, they belong to a later geological period.

On the little island Oersa, we pass over the upturned edges of similar rocks. The gneiss has the same greenish-grey tinge, and is traversed by veins of a bright pink granitic variety, which graduates into a granular pinkish-grey. Along the precipitous face of the bold sea-cliffs, deep indentations have been made into the softer interstratified schist and junctions of the intrusive igneous rocks, by the erosive action of the Atlantic waves.

The dip and strike of the stratified rocks are much altered by the intrusive igneous rocks. The general dip, however, is to the s.s.w., until we reach Bruthac a' chladaich, near where the stratified rocks to the south-east all dip steadily to the S.E. The junction of the quartzite and calcareous deposits is marked by alternating beds or bands of the two rocks, showing at short intervals a repetition of previously existing conditions. Though marked in the outcrop as very distinct, they are nevertheless found on close inspection to present almost imperceptible gradations from one to the other.

Having thus briefly sketched the general characters and relations of these deposits, the question remains to be answered, Do they 
furnish us with sufficient evidence to warrant us in determining their age ?

The sequence of the groups may be shortly described as follows:-

1. The sandstones which form the southern extent of the island, known as the Mull of $\mathrm{Oa}$, and the schistose rocks which skirt the shore from Port Ellen, Kildalton, to Ard-tala bay, and for three miles inland, belong to the lower members of the lower Silurian period.

2. The quartzites which underly the schistose rocks, and of which the mountains on the east side of the island are built up, and which trend southwards with the underlying slates and calcareous deposits that fill up the centre of the island, are of Upper Cambrian age.

3. The deposits from Aird na h-abhann on the north to Baile Iochd-arach on the south, along the Sound of Islay, the conglomerates, the argillaceous deposits and dark quartzites found from Skerrols to the north of Islay House, and to the north-west, as far as Sanaig, are Lower Cambrian.

Although I have not seen the precise equivalents of those greenish-grey micaceous flags, with chocolate argillaceous partings, on the north side of Big Free-Port Bay, on which we find suncracks, rain prints, and what are sometimes supposed to be the tracks of annelids, they coincide well with similar rocks, defined as of Cambrian age by the late Sir R. Murchison, and which occur in Sutherlandshire, where their relation to an inferior conglomeritic mass is so clearly traced. Also with those described by the late $\mathrm{Mr}$ Salter and Dr Hicks, from the Longmynd beds in Wales. I think that it is almost unnecessary to adduce further facts. If similarity of physical conditions, and similarity of fossil forms are to guide us in determining the relations of formations, then those stratified rocks seen along the north-eastern side and centre of the island, folding over and surrounding the conglomerate mass, and that group near Sanaig should be placed in a similar stratigraphical position to those described by the above authors, thus extending the range of Cambrian rocks further south in the Highlands of Scotland than has been hitherto recorded.

Professor Ramsay suggests that probably the Cambrian argillaceous beds were deposited under fresh-water conditions. That they were deposited in an inland lake cannot be doubted, 
THOMSON-ON THE GEOLOGY OF ISLAND OF ISLAY.

and that these cracks are due to the influence of the sun is abundantly evident. If they had been deposited in an estuary of the sea, the soft mud would not have got time to crack, as each inflowing tide would have kept the matrix sufficiently moist to prevent it from shrinking and cracking.

4. The metamorphic rocks on the western extremity of the island, and skirting the shore of Lochin-dala for nine miles, and dipping s.s.w., are of Laurentian age. The limited time at my disposal did not enable me to give in detail a description of this interesting group. After the examination I did give them, I felt convinced that these crystalline stratified rocks belong to a very different period of time from those found in the central valley and southeastern side of the island. There can therefore be little doubt regarding their proper identification; their lithological aspect and mineral characters coincide so well with the fundamental gneiss of Sutherlandshire, described by Sir R. Murchison, and designated by him as of Laurentian age. Indeed, on putting hand specimens of these rocks and rocks similar in crystallization, from the Outer Hebrides, e.g., Harris, North Uist, Lewis, and from Sutherland on the mainland, into the hands of some of our ablest geologists, they all classified them as belonging to the same group. Although we have evidence highly suggestive, we are yet unprepared to speak with any degree of certainty regarding the source or direction of the materials constituting the basic conglomerate mass on the east side and north centre of the island. If, however, we glance at the topographical aspect of the Highlands and islands, and compare the boulders with the granites throughout the Highlands, we feel the necessity of tracing them to another source. And we hope we do not overstep the bounds of prudent speculation in suggesting that these erratics are the re-assorted materials of some great Northern Continent which has yielded to the ceaseless gnawing tooth of time, leaving those scattered fragments as the wreckage of its former greatness; and that the materials of which the mass is composed, have been transported by the agency of ice. The mineral characters of these boulders differ so widely from the granites at present found in situ throughout the Highlands, that a much higher antiquity for those found in Islay is suggested, while the finding of the glaciated rock at the base of the mass stamps their true character, and points to a period of time deeper than we have hitherto suspected; 
TRANSAOTIONS OF THE GEOLOGICAT SOC. OF GLASGOW.

when glaciers and icebergs planed the hardest rocks, and transported matter, as they still do, obedient to one great law.

In conclusion, I may say that, had more time been at my disposal, I should have spoken more exhaustively upon some of the interesting geological phenomena of the island; yet, although imperfectly, I hope enough has been said to interest other observers with more leisure, and better fitted to do the subject the justice which it merits.

To Mr Ramsay of Kildalton, M.P., and to Mr Finlay of Losset, who kindly allowed me free passage over their estates, my thanks are due; as also to $\mathrm{Mr}$ James Scott, and to Mr Colin Hay, who frequently guided me to many of the points referred to. I am also much indebted to $\mathrm{Mr}$ Hector M'Lean, teacher, who gave me the proper readings of the Gaelic names mentioned in my paper.

XIV.-Geological Notes on the Cutrings IN THE CITY of Glasgow UNion RAILWAY BETWEEN BeLlgROVE and Springburn. By James NeILson, jun.

[Read 13th May, 1875.]

THE branch line connecting the College and Sighthill Stations of the North British Railway, was made principally to relieve the Queen Street terminus-long inadequate for the purposefrom the ever-increasing goods traffic. Although only about one mile and a half in length, its cost has been great, as besides heavy cuttings, with much building in and tunnelling, the Monkland Canal had to be diverted, and a new bed half a mile in length constructed.

Minerals have been long and extensively worked in the district. I remember a deserted coal pit and a sandstone quarry where the Camlachie goods station now stands, while another pit was till lately visible near the Cumbernauld Road, about 100 yards north of Duke Street. Craigpark whinstone quarry and Blochairn sand quarry are still being worked. Although, owing to the thick overlying deposits of clay, the locality has been so barren to the geologist as not to have been mentioned in the Transactions of the Society except in one instance, and then only to state that nothing of interest was to be seen, yet I do not know any place, where, within the space of a mile, there can be seen more 